\title{
Peningkatan Kapasitas Pembudidaya Ikan Melalui Optimalisasi Fungsi Wahana Pembelajaran Kelompok
}

\author{
[Increasing the Capacity of Fish Farmers through Optimization of the Function \\ of Group Learning Vehicles]
}

\author{
Nayu Nurmalia, Ani Lutfiyanah, Minarni, Agus Prastiyo, \\ Muhammad Arya Pratama Putra, Nisfi Darwita, Welas Ayu
}

\author{
Program Studi Penyuluhan Perikanan Politeknik AUP \\ Jalan Cikaret No 2 Po Box 16002
}

\begin{abstract}
Abstrak
Fungsi wahana pembelajaran kelompok akan berdampak positif terhadap peningkatan kapasitas pembudidaya ikan pada saat terjadi peningkatan aspek pengetahuan dan sikap mengenai fungsi kelompok dan administrasi kelompok. Kondisi terkini adalah penerapan fungsi kelompok yang belum optimal dikarenakan kerja sama antar anggota kelompok belum berjalan baik, serta kurangnya pengetahuan dan sikap mengenai fungsi kelompok dan administrasi kelompok. Hal ini terlihat pada (1) kelompok Mina Mukti dan Cipta Rasa Kecamatan Darmaraja Kabupaten Sumedang Provinsi Jawa Barat; (2) kelompok Mina Harapan, Kedung Bulus dan Rukun Makmur Kecamatan Pangadegan Kabupaten Purbalingga Provinsi Jawa Tengah; dan (3) kelompok Pokdakan Mina Mulya Kecamatan Landasan Ulin Kota Banjarbaru Provinsi Kalimantan Selatan. Kegiatan ini bertujuan untuk meningkatkan aspek sikap dan pengetahuan mengenai fungsi kelompok dan administrasi kelompok melalui penyuluhan. Kegiatan penyuluhan dilaksanakan selama tiga bulan, mulai tanggal 19 Februari sampai dengan 19 Mei 2018. Metode pengambilan data primer melalui wawancara dengan alat bantu kuesioner. Data sekunder didapatkan dari laporan tahunan dinas, studi literatur dan internet Hasil kegiatan penyuluhan dianalisis dengan menggunakan analisis kualitatif, kuantitatif dan deskriptif. Hasil yang diperoleh menunjukkan terjadi peningkatan aspek pengetahuan sebesar $26 \%-40 \%$ dan aspek sikap antara $10 \%-18 \%$.
\end{abstract}

Kata kunci: fungsi dan administrasi kelompok; kapasitas; pembudidaya ikan; penyuluhan

\section{Abstract}

The function of group learning vehicles will have a positive impact on increasing the capacity of fish farmers if there is an increase in the aspects of knowledge and aspects of attitudes regarding the function of the group and group administration. The current condition is that the application of group functions has not been optimal, with regard to promoting collaboration between group members not yet materialized; and lack of knowledge and attitudes regarding group functions and group administration. This can be seen in (1) the Mina Mukti and Cipta Rasa group, Darmaraja District, Sumedang Regency, West Java Province; (2) the Mina Harapan, Kedung Bulus and Rukun Makmur groups, Pangadegan District, Purbalingga Regency, Central Java Province; and (3) the Mina Mulya Pokdakan group, Landasan Ulin District, Banjarbaru City, South Kalimantan Province. This activity aims to improve aspects of attitudes and knowledge regarding group functions and group administration through counseling. Extension activities were carried out for three months, starting from February 19 to May 19 2018. The primary data collection method was through interviews with questionnaire tools. Secondary data were obtained from official annual reports, literature studies and the internet. The results of outreach activities were analyzed using qualitative, quantitative and descriptive analyzes. The results obtained indicate an increase in the knowledge aspect by $26 \%-40 \%$ and the attitude aspect between $10 \%-18 \%$.

Keywords: capacity; extension; fish farmers; group functions and administration 
Penulis Korespondensi

Nayu Nurmalia | nayunurmalia@yahoo.com

\section{PENDAHULUAN}

Perubahan perilaku yang bersifat kontinu, fungsional, positif, aktif, dan terarah sebagai hasil interaksi individu dengan lingkungannya merupakan suatu proses belajar. Proses belajar dan pembelajaran dapat dilihat melalui tingkat keberhasilan dalam mencapai tujuan. Pembelajaran merupakan keberhasilan tujuan yang diharapkan secara optimal dengan melibatkan satu kesatuan komponen yang saling berkaitan dan saling berinteraksi antara pendidik dengan peserta didik dan sumber belajar yang berlangsung dalam suatu lingkungan belajar (Pane dan Darwis Dasopang 2017). Efektivitas sebuah proses belajar dan pembelajaran ditentukan oleh interaksi di antara komponen-komponen tersebut untuk mencapai tujuan. Menurut Nurmalia dan Susilawati (2016) efektivitas adalah pencapaian tujuan secara tepat atau memilih tujuan yang tepat dari serangkaian alternatif atau pilihan cara dan menentukan pilihan dari pada beberapa pilihan lainnya.

Peningkatan produktivitas, efisiensi usaha, pendapatan, dan kesejahteraan, serta meningkatkan kesadaran adalah upaya dalam pelestarian fungsi lingkungan hidup. Dalam hal ini pembelajaran yang dilakukan yaitu dengan menggunakan pendekatan kelompok untuk meningkatkan pengetahuan tentang fungsi kelompok serta administrasi kelompok agar kelompok mau dan mampu menolong dan mengorganisasikan kelompoknya dalam mengakses informasi pasar, teknologi, permodalan, dan sumber daya lainnya untuk mencapai tujuan yang ingin dicapai.

Pendekatan kelompok sampai saat ini masih digunakan dalam kegiatan penyuluhan. Pendekatan kelompok dipandang lebih efisien dan dapat menjadi media untuk terjadinya proses belajar dan berinteraksi dari pembudidaya, sehingga diharapkan terjadi perubahan perilaku pembudidaya ke arah yang mandiri, lebih baik, dan berkualitas sehingga dapat mencapai tujuan bersama (Sadono 2008).

Faktor yang memengaruhi kekompakan kelompok yaitu: kepemimpinan kelompok, keanggotaan kelompok, nilai tujuan kelompok, homogenitas anggota kelompok, keterpaduan keikatan kelompok, jumlah anggota kelompok (Hanan 2015). Kelompok dapat diartikan sebagai kumpulan yang terdiri dari dua atau lebih individu dan saling berinteraksi satu sama lain dalam ikatan yang saling memengaruhi untuk mencapai tujuan bersama. Berdasarkan keenam faktor 
tersebut, maka pendekatan kelompok dalam mengoptimalkan fungsi wahana pembelajaran sangat diharapkan pembudidaya untuk dapat meningkatkan pengetahuan dan sikap tentang fungsi kelompok, administrasi kelompok dan kekompakan serta kerja sama dalam berkelompok sehingga berpengaruh terhadap pendapatan pembudidaya untuk lebih meningkat. Kekompakan kelompok menunjukkan tingkat rasa untuk tetap tinggal dalam kelompok, hal ini dapat berupa: loyalitas, rasa memiliki, rasa keterlibatan, dan keterikatan. Tujuan dari kegiatan ini adalah meningkatkan aspek pengetahuan dan sikap mengenai fungsi kelompok dan administrasi kelompok.

\section{BAHAN DAN METODE}

Penelitian ini dilaksanakan selama tiga bulan, mulai tanggal 19 Februari hingga 19 Mei 2018 , bertempat di tiga lokasi, yaitu: 1) Provinsi Jawa Barat, Kabupaten Sumedang, yaitu di Kecamatan Darmaraja pada kelompok Mina Mukti dan Cipta Rasa; 2) Provinsi Jawa Tengah, Kabupaten Purbalingga, yaitu di Kecamatan Pangadegan pada kelompok Mina Harapan, Kedung Bulus dan Rukun Makmur; dan 3) Provinsi Kalimantan Selatan, Kota Banjarbaru, yaitu di Kecamatan Landasan Ulin pada kelompok Pokdakan Mina Mulya. Metode pengambilan data primer menggunakan sis- tem wawancara dengan alat bantu kuesioner. Data sekunder didapatkan dari pengumpulan data dan informasi berupa laporan tahunan dinas, studi literatur dan internet Data dianalisis secara kualitatif, kuantitatif, dan deskriptif. Untuk pengelolaan data dan pengukuran hasilnya menggunakan skala likert. Metode kualitatif adalah metode riset yang bersifat deskriptif, menggunakan analisis, dan mengacu pada data. Metode kuantitatif adalah metode dengan menggunakan data numerik dan menekankan proses penelitian pada pengukuran hasil yang objektif. Skala likert adalah suatu skala psikometri yang umumnya digunakan dalam angket dan merupakan skala yang paling banyak digunakan dalam riset berupa survei.

Sasaran yang dituju yaitu seluruh anggota kelompok pembudidaya ikan. Metode penelitian yang digunakan dalam kegiatan ini yaitu demonstrasi cara, ceramah, diskusi, wawancara dan anjangsana.

Untuk metode deskriptif evaluasi terhadap peningkatan kapasitas pembudidaya ikan melalui optimalisasi fungsi wahana pembelajaran kelompok menggunakan rumus :

$$
\text { Perubahan }=\frac{\text { Nilai }_{1}-\text { Nilai }_{0}}{\text { Nilai tertinggi }} \times 100 \%
$$

Keterangan:

Nilai ${ }_{1}$ : nilai akhir

Nilaio: nilai awal

$$
\text { Perubahan }=\text { Post Test }- \text { Pre Test }
$$


Rumus Index ( \%) $=\frac{\text { Jumlah skor }}{\text { Skor tertinggi }} \times 100 \%$

Skala likert menggunakan bebera-

pa tahapan dalam evaluasi terhadap

peningkatan kapasitas pembudidaya ikan melalui optimalisasi fungsi wahana pembelajaran kelompok. Untuk menentukan indeks menggunakan rumus persentase indeks seperti di atas.

Tabel 1. Evaluasi peningkatan aspek pengetahuan fungsi dan administrasi kelompok

\begin{tabular}{|c|c|c|c|}
\hline $\begin{array}{c}\text { No } \\
\text { Responde } \\
\text { n }\end{array}$ & $\begin{array}{c}\text { Kec. Darmaraja, Kab. } \\
\text { Sumedang, Prov. Jawa } \\
\text { Barat }{ }^{1)}\end{array}$ & $\begin{array}{l}\text { Kec. Landasan Ulin, Kota } \\
\text { Banjarbaru, Prov. Kalsel }{ }^{2}\end{array}$ & $\begin{array}{c}\text { Kec. Pangadega } \\
\text { Kab. Purbalingg } \\
\text { Prov. Jawa Tenga }\end{array}$ \\
\hline 1. & $40 \%$ & $50 \%$ & $30 \%$ \\
\hline 2. & $40 \%$ & $20 \%$ & $20 \%$ \\
\hline 3. & $40 \%$ & $30 \%$ & $30 \%$ \\
\hline 4. & $20 \%$ & $20 \%$ & $30 \%$ \\
\hline 5. & $60 \%$ & $30 \%$ & $20 \%$ \\
\hline 6. & $40 \%$ & $30 \%$ & $30 \%$ \\
\hline 7. & $40 \%$ & $30 \%$ & $20 \%$ \\
\hline 8. & $40 \%$ & $50 \%$ & $20 \%$ \\
\hline 9. & $60 \%$ & $30 \%$ & $40 \%$ \\
\hline 10. & $20 \%$ & $30 \%$ & $20 \%$ \\
\hline Rata-rata & $40 \%$ & $32 \%$ & $26 \%$ \\
\hline
\end{tabular}

Sumber: Ayu (2019); Darwita (2019); Putra (2019)

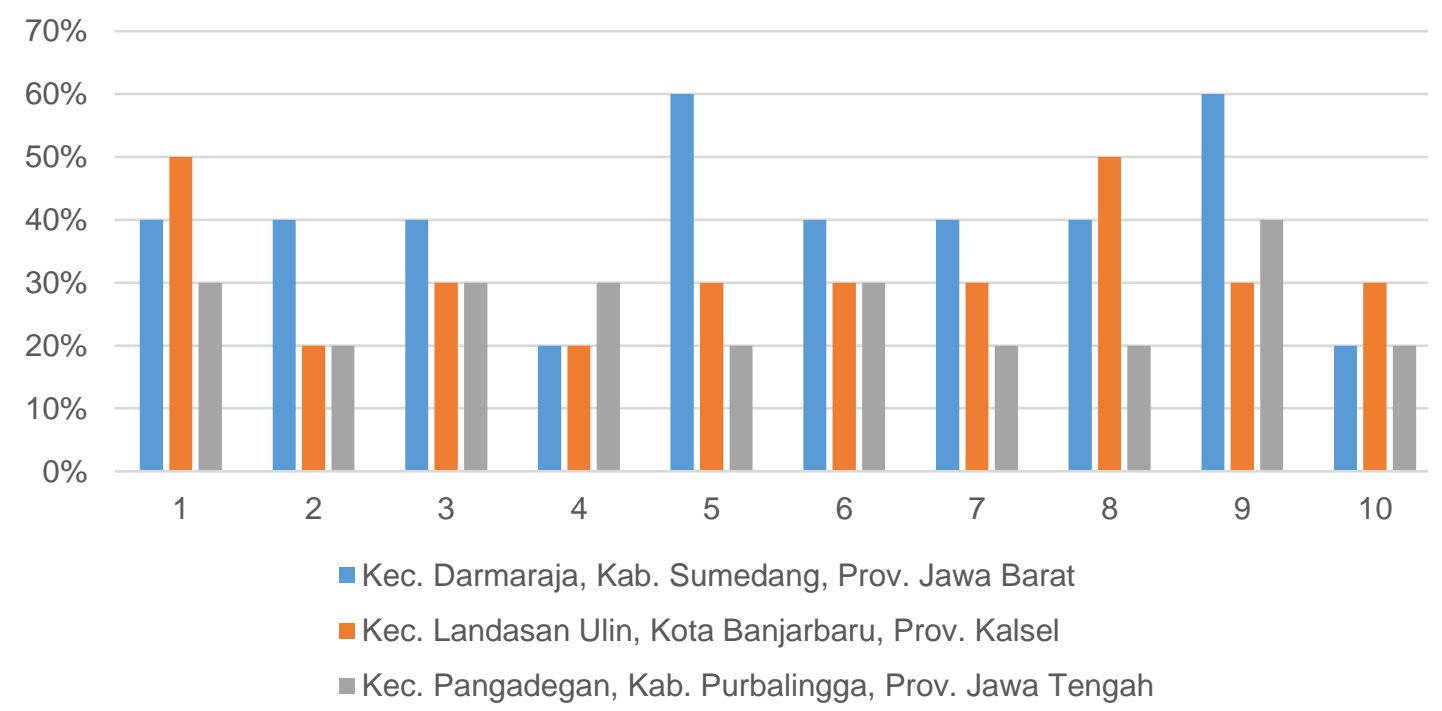

Gambar 1. Perubahan aspek pengetahuan fungsi kelompok dan administrasi kelompok 


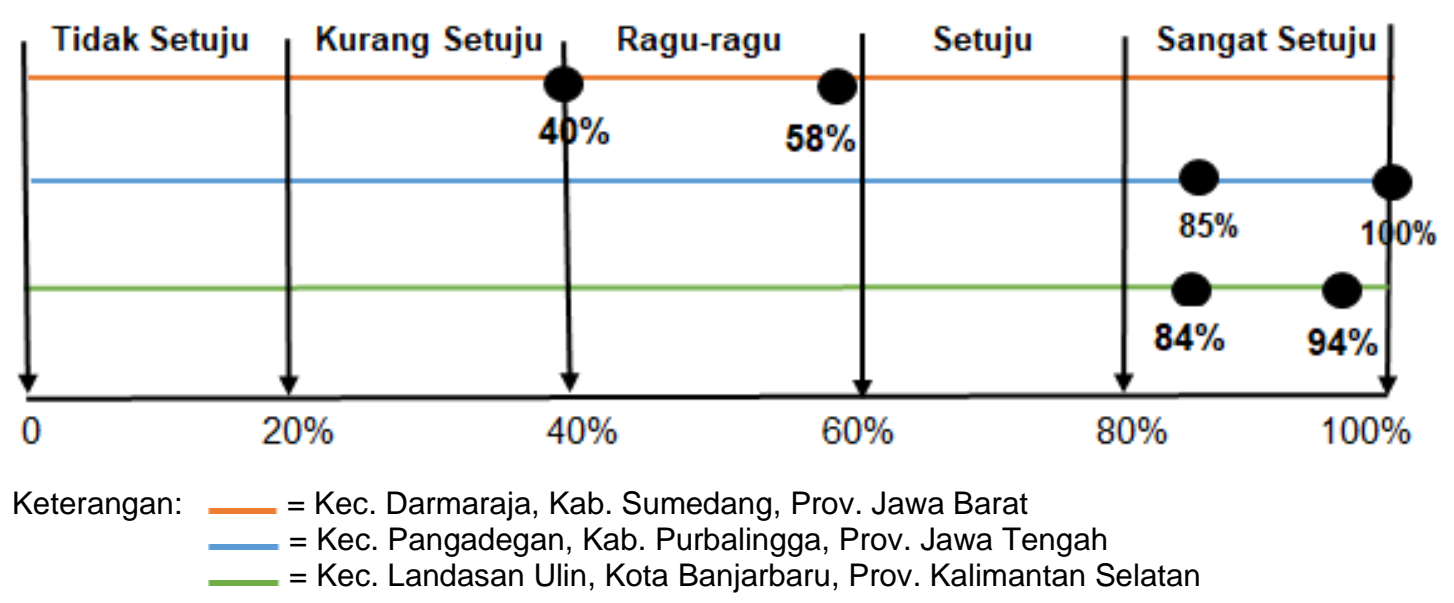

Gambar 2. Garis kontinum dari analisis skala likert untuk aspek sikap

Tabel 2. Perubahan aspek sikap mengenai fungsi kelompok dan administrasi kelompok

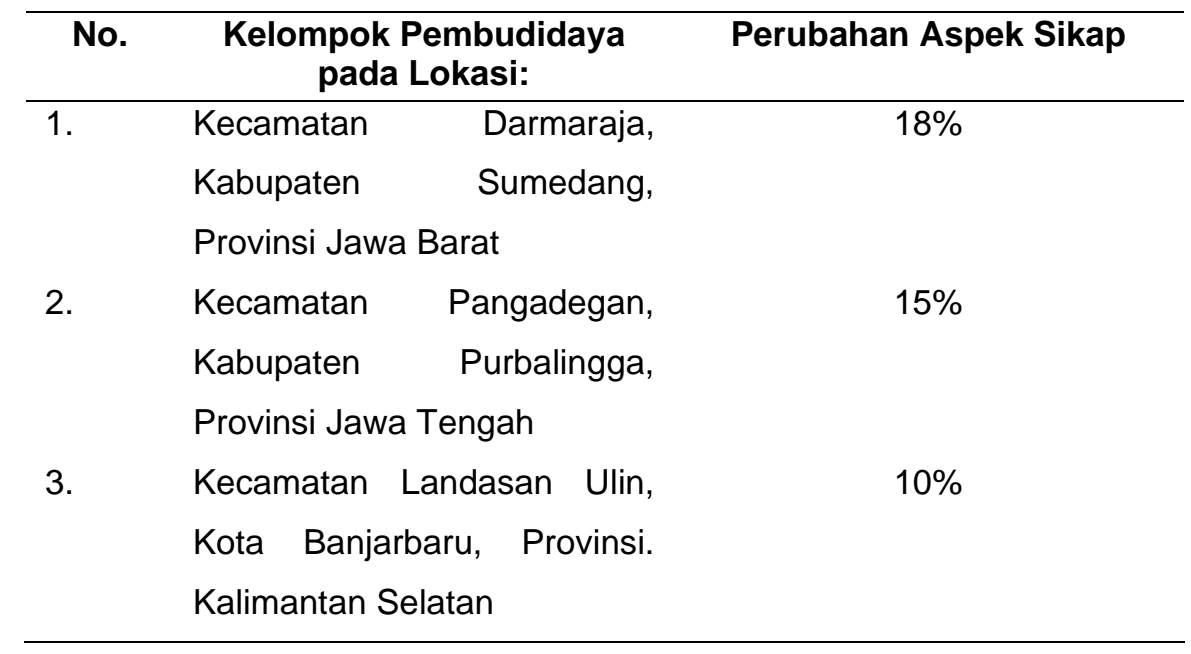

\section{HASIL DAN PEMBAHASAN}

\section{Hasil}

Untuk mengetahui perbedaan hasil antara kelompok pembudidaya pada tiga lokasi pengamatan, dilakukan evaluasi untuk aspek pengetahuan dan aspek sikap mengenai fungsi dan administrasi kelompok. Untuk aspek pengetahuan dilakukan dengan metode kualitatif dan deskriptif dengan melakukan evaluasi pre-test dan post-test yaitu berupa pertanyaan mengenai pengetahuan tentang fungsi kelompok dan administrasi kelompok. Setelah diolah, hasil evaluasi peningkatan aspek pengetahuan mengenai fungsi dan administrasi kelompok pada ketiga daerah, dapat dilihat pada Tabel 1, Gambar 1 dan 2 berikut ini.

Evaluasi aspek sikap dilakukan dengan metode kualitatif dan deskriptif 
dengan melakukan evaluasi pre-test dan post-test yaitu berupa beberapa pernyataan mengenai pengetahuan tentang fungsi kelompok dan administrasi kelompok yang harus dijawab oleh responden. Setelah diperoleh data kemudian dapat diolah menggunakan skala likert sehingga dapat diketahui perubahan yang diperoleh. Adapun penilaian skala likert yang digunakan adalah sebagai berikut: 1) tidak setuju; 2) kurang setuju; 3) ragu-ragu; 4) setuju; 5) sangat setuju. Dari hasil yang didapat untuk aspek sikap terjadi peningkatan pada ketiga daerah, hal ini dapat dilihat secara rinci pada garis kontinu sebagaimana terlihat pada Gambar 1.

Perubahan aspek sikap diperoleh dengan menggunakan rumus:

$$
\text { Perubahan }=\text { Post Test }- \text { Pre Test }
$$

Nilai perubahan aspek sikap tentang fungsi kelompok dan administrasi kelompok, dapat dilihat secara rinci pada Tabel 2.

\section{Pembahasan}

Data Tabel 1 menggambarkan aspek pengetahuan terhadap fungsi wahana pembelajaran kelompok dengan nilai tertinggi diperoleh pada Pokdakan yang berada di Kecamatan Darmaraja, Kabupaten Sumedang, Provinsi Jawa Barat yaitu $40 \%$ : kemudian diikuti berturut-turut oleh Pokdakan yang berada di Kecamatan Landasan Ulin, Kota Banjarbaru, Provinsi Kalimantan Selatan yaitu 32\%; dan Pokdakan yang berada di Kecamatan Pangadegan, Kabupaten Purbalingga, Provinsi Jawa Tengah yaitu $26 \%$. Perubahan aspek pengetahuan yang diperoleh yaitu karena dipengaruhi oleh beberapa karakteristik sasaran yaitu umur, pendidikan formal, dan lama usaha.

\section{Umur}

Umur merupakan salah satu faktor yang memengaruhi perilaku dalam melakukan atau mengambil keputusan dan dapat bekerja secara optimal serta produktif. Umur dapat dikategorikan menjadi: 1) produktif (15-64 tahun); 2) tidak produktif (< 15 tahun); 3) kurang produktif (>64 tahun). Dilihat dari sisi umur, Pokdakan pada tiga lokasi penyuluhan, yaitu pada umur pembudidaya baik di Kecamatan Darmaraja, Kabupaten Sumedang, Provinsi Jawa Barat, maupun di Kecamatan Landasan Ulin, Kota Banjarbaru, Provinsi Kalimantan Selatan; serta di Kecamatan Pangadegan, Kabupaten Purbalingga, Provinsi Jawa Barat; ratarata berumur pada kisaran 40 tahun.

Kisaran umur pembudidaya pada ketiga daerah tersebut merupakan umur yang produktif. Hal ini sesuai dengan Undang-Undang Nomor 13 tahun 2003 tentang Ketenagakerjaan bahwa usia 
produktif yaitu antara 15-64 tahun. Umur pembudidaya pada ketiga daerah merupakan umur pertengahan. Yani, Setijorini, dan Noviyanti (2010) mengemukakan bahwa jika terdapat (50\%) responden berusia dewasa pertengahan (usia 40-53 tahun), maka hal tersebut menunjukkan bahwa anggota kelompok sebagian besar berusia produktif dan mampu menjalankan aktivitas usaha tani, serta dapat berinteraksi dengan anggota kelompoknya. Masa pertengahan merupakan masa puncak di mana terjadi interaksi antara pria dan wanita dalam bermasyarakat dan pekerjaannya (Yani, Pertiwi, dan Sigit 2013).

Berdasarkan uraian di atas, dapat dikatakan bahwa sisi umur berpengaruh terhadap perubahan aspek pengetahuan pada pembudidaya di tiga lokasi penyuluhan. Karena pada masa produktif merupakan umur ideal bagi para pembudidaya karena sudah mempunyai pengalaman dan mudah dalam menyerap ilmu pengetahuan. Secara umum, semakin bertambahnya umur maka pengetahuan akan meningkat dan berdampak pada pendapatan yang semakin meningkat pula (Putri dan Setiawina 2013).

\section{Pendidikan Formal}

Pendidikan formal adalah lama tahun yang ditempuh pembudidaya dalam mengikuti sekolah formal yang berdasarkan jenjang sekolah dasar sampai perguruan tinggi. Hasil pengukuran dikategorikan menjadi: 1) dasar; 2) menengah; dan 3) tinggi. Tingkat pendidikan pembudidaya berturut-turut dengan jumlah persentase tertinggi adalah di Kecamatan Darmaraja, Kabupaten Sumedang, Provinsi Jawa Barat sebesar 26\% pendidikan menengah dan $74 \%$ berpendidikan dasar; disusul berikutnya di Kecamatan Landasan Ulin, Kota Banjarbaru, Provinsi Kalimantan Selatan, sebanyak $20 \%$ pendidikan menengah dan $80 \%$ berpendidikan dasar; dan terakhir Kecamatan Pangadegan, Kabupaten Purwakarta, Provinsi Jawa Barat, sebanyak $100 \%$ adalah berpendidikan dasar. Sebagaimana UndangUndang Nomor 20 tahun 2003 tentang Sistem Pendidikan Nasional menguraikan bahwa pendidikan adalah usaha sadar dan terencana untuk mewujudkan suasana belajar dan proses pembelajaran agar peserta didik secara aktif mengembangkan potensi dirinya untuk memiliki kekuatan spiritual keagamaan, pengendalian diri, kepribadian, kecerdasan serta keterampilan yang diperlukan masyarakat, bangsa, dan Negara.

Berdasarkan uraian bahwa dengan mengenyam pendidikan, terbentuk dan memunculkan usaha sadar untuk mengembangkan potensi diri, maka jelas terlihat perbedaan persentase pendidikan pembudidaya dengan persentase 
tertinggi adalah $26 \%$ berpendidikan menengah dan $74 \%$ berpendidikan dasar. Persentase tersebut sangat memengaruhi perubahan pada aspek pengetahuan terhadap fungsi wahana pembelajaran kelompok di Kecamatan Darmaraja, Kabupaten Sumedang, Provinsi Jawa Barat lebih tinggi. Hal ini dikarenakan pendidikan merupakan suatu indikator seseorang untuk melihat mutu dan sumber daya anggota kelompok tani. Tingkat pendidikan menentukan tingkat pemahaman materi penyuluhan, keterampilan, berkomunikasi, dan sikap terhadap metode penyuluhan yang diterapkan. Pendidikan formal juga akan memengaruhi perilaku, pola pikir, kreativitas, dan keterampilan dalam melakukan usaha taninya dan kehidupan bermasyarakat.

\section{Lama Usaha}

Lama usaha adalah jumlah tahun yang dilalui pembudidaya sebagai bagian dari proses belajar dalam kegiatan budidaya, produksi dan seluk beluk usaha dan pemasaran hasil panen dalam rangka memperoleh penghasilan. Pengalaman usaha pembudidaya ikan diklasifikasikan dalam kategori: 1) Pengalaman baru adalah kurang dari 10 tahun; 2) Pengalaman sedang berkisar antara 10-20 tahun; 3) Pengalaman lama lebih dari 20 tahun. Lama usaha pembudidaya di daerah Kecamatan Landa- san Ulin, Kota Banjarbaru, Provinsi Kalimantan Selatan adalah baru merintis dan masih dalam proses pembelajaran; disusul di Kecamatan Darmaraja, Kabupaten Sumedang, Provinsi Jawa Barat rata-rata lama usaha pembudidaya yaitu lima tahun; dan terakhir di daerah Kecamatan Pangadegan, Kabupaten Purbalingga, Provinsi Jawa Tengah rata-rata lama usaha pembudidaya yaitu enam tahun.

Dari data di atas lama usaha pada ketiga daerah yaitu kurang dari 10 tahun dan termasuk dalam katagori pengalaman yang masih baru, sehingga pembudidaya hanya mengikuti apa yang telah mereka lihat dari sesama pembudidaya ikan, yang dianggap sesuai dengan teknik budidaya ikan yang dianjurkan. Manyamsari dan Mujiburrahmad (2014), mengemukakan bahwa pembudidaya ikan yang sudah lama melakukan aktivitas kegiatan budidaya akan lebih mudah untuk menerapkan anjuran penyuluh.

Menurut Priyandika (2015) lamanya usaha seseorang dapat meningkatkan pengetahuannya dan akan berpengaruh pada tingkat pendapatannya. Semakin lama seseorang menekuni usahanya maka akan meningkat pula pengetahuan mengenai teknologi, perilaku pasar, dan modal dalam usaha yang dijalankannya. Oleh karena itu, dapat dikatakan dari sisi lama usaha berpengaruh terhadap perubahan pada 
aspek pengetahuan dari kondisi pembudidaya di tiga lokasi penyuluhan.

Data Tabel 2. menggambarkan perubahan aspek sikap terhadap fungsi wahana pembelajaran kelompok dengan nilai tertinggi juga diperoleh pada Kecamatan Darmaraja, Kabupaten Sumedang, Provinsi Jawa Barat yaitu 18\% dibanding dengan di Kecamatan Pangadegan, Kabupaten Purbalingga, Provinsi Jawa Tengah (15\%) dan Kecamatan Landasan Ulin, Kota Banjarbaru, Provinsi Kalimantan Selatan (10\%). Perubahan aspek sikap yang diperoleh yaitu selain karakteristik umur, pendidikan formal, dan lama usaha juga karena dipengaruhi oleh beberapa karakteristik sasaran lainnya yaitu seperti partisipasi, dan motivasi.

\section{Partisipasi}

Partisipasi kelompok merupakan keikutsertaan anggota baik secara individu maupun secara kelompok dengan penuh kesadaran dan tanggung jawab dalam bidang usaha (Koampa et al. 2015). Tingkat partisipasi dihitung dengan skala likert sehingga menghasilkan garis kontinum. Tingkat partisipasi dapat meningkatkan kesadaran masyarakat sehingga mereka mampu berinisiatif sendiri, memengaruhi proses dan hasil usaha, dan meningkatkan kapasitas masyarakat sehingga mereka mampu meningkatkan efisiensi dan efektivitas usaha (Kogoya, Olfie, dan Laoh 2015).

Pada hasil di atas, menunjukkan bahwa tingkat partisipasi pada daerah di Kecamatan Darmaraja, Kabupaten, Sumedang, Provinsi Jawa Barat kurang, yaitu dari kurang setuju menjadi raguragu tetapi perubahan yang diperoleh yaitu 18\%. Untuk di Kecamatan Pangadegan, Kabupaten Purbalingga, Provinsi Jawa Tengah tingkat partisipasi yang diperoleh yaitu dari sangat setuju menjadi sangat setuju dengan hasil perubahan yaitu 15\%. Dan untuk di Kecamatan Landasan Ulin, Kota Banjarbaru, Provinsi Kalimantan Selatan yaitu menunjukkan sangat setuju menjadi sangat setuju dengan hasil perubahan yaitu $10 \%$. Perubahan aspek sikap terhadap fungsi wahana pembelajaran kelompok pada ketiga daerah belum optimal karena hanya terjadi perubahan yaitu antara $10 \%-18 \%$. Hal ini karena pendidikan pada ketiga daerah adalah rata-rata berpendidikan dasar sehingga kurangnya partisipasi dari para pembudidaya. Faktor yang memengaruhi tingkat partisipasi menurut Ulfa, Marwanti, dan Utami (2015), yaitu pendidikan yang merupakan salah satu aspek yang berpengaruh pada tingkat berpikir dan bertindak pembudidaya dalam menerima informasi yang disampaikan penyuluh. Dari pernyataan tersebut dapat dikatakan bahwa partisipasi berhubungan erat dengan 
pendidikan pembudidaya dan akan berpengaruh pada perilaku pembudidaya. Semakin tinggi tingkat pendidikan pembudidaya maka semakin tinggi pula tingkat partisipasi dan keikutsertaan pembudidaya dan akan berdampak pada perilaku pembudidaya yang dapat meningkatkan hasil usaha yang dijalankannya.

\section{Motivasi}

Motivasi merupakan pemberian dorongan yang penting dilakukan untuk meningkatkan gairah kerja sehingga dapat mencapai hasil yang dikehendaki. Hubungan motivasi, gairah kerja dan hasil optimal mempunyai bentuk linear dalam arti dengan pemberian motivasi yang baik, maka gairah kerja kelompok akan meningkat dan hasil kerja akan optimal. Tingkat motivasi dihitung dengan menggunakan skala likert yang menghasilkan garis kontinum. Skala likert yaitu jenis skala yang digunakan untuk mengukur persepsi seseorang atau sekelompok orang tentang fenomena sosial (Sugiyono 2015). Adapun penilaian skala likert yang digunakan adalah sebagai berikut: 1) tidak setuju; 2) kurang setuju; 3) ragu-ragu; 4) setuju; 5) sangat setuju.

Hasil yang didapat yaitu bahwa di Kecamatan Darmaraja, Kabupaten Sumedang, Provinsi Jawa Barat setelah dilakukan penyuluhan masih dalam kategori ragu-ragu (Darwita 2018). Hal ini dikarenakan kesadaran anggota kelompok masih rendah dan masih ketergantungan pada ketua kelompok. Sebagaimana yang diungkapkan Ramadoan, Muljono, dan Pulungan (2013), bahwa apa pun motivasi yang mendorong pembudidaya untuk mengikuti penyuluhan, apakah itu termotivasi karena kesadaran diri, terpaksa atau desakan dari orang lain atau hanya untuk mendapatkan keuntungan. Untuk di Kecamatan Pangadegan, Kabupaten Purbalingga, Provinsi Jawa Tengah setelah dilakukan penyuluhan sudah pada kategori sangat setuju. Hal ini karena pada saat sebelum penyuluhan sudah pada kategori sangat setuju kemudian terdapat perubahan yaitu $15 \%$. Menurut Ayu (2018) di Kecamatan Pangadegan, Kabupaten Purbalingga, Provinsi Jawa Tengah telah melakukan komunikasi antar anggota kelompok dalam memecahkan masalahnya sendiri, tanpa adanya ketergantungan pada ketua kelompok, atau penyuluh. Untuk di Kecamatan Landasan Ulin, Kota Banjarbaru, Provinsi Kalimantan Selatan setelah dilakukan penyuluhan sudah pada katagori sangat setuju. Hal ini karena pada saat sebelum penyuluhan sudah pada katagori sangat setuju sehingga terdapat perubahan 10\%. Menurut Putra (2018) bahwa di Kecamatan Landasan Ulin, Kota Banjarbaru, Provinsi Kalimantan Selatan para pembudidaya 
mempunyai keinginan untuk maju dalam usaha yang dijalankan.

Dari hasil di atas dapat dikatakan bahwa motivasi sangat berpengaruh pada perubahan aspek sikap pembudidaya. Hal ini diperkuat oleh Brahmasari dan Suprayetno (2008) bahwa motivasi berpengaruh positif dan signifikan terhadap perilaku seseorang, artinya bahwa motivasi kerja memang sangat diperlukan oleh seseorang untuk dapat mencapai suatu hasil yang maksimal dan akan menjadi kepuasan tersendiri dengan hasil yang didapatkan.

Karakteristik di atas sangat memengaruhi perubahan aspek pengetahuan dan aspek sikap fungsi wahana pembelajaran kelompok. Dari hasil yang ada dapat diketahui bahwa setelah dilakukan penyuluhan terdapat perubahan-perubahan pada kelompok di ketiga daerah yaitu seperti: 1) Kelompok sudah melakukan pertemuan kelompok secara berkala yaitu setiap satu bulan sekali guna bertukar pikiran dalam mengelola usaha perikanan secara bersama; 2) Telah tersedianya tempat khusus pertemuan dan sarana prasarana kelompok; 3) Antar anggota kelompok sudah saling bekerja sama dalam memecahkan masalah.

\section{SIMPULAN DAN SARAN}

Hasil yang diperoleh dari kegiatan penyuluhan yaitu melalui optimalisasi fungsi wahana pembelajaran kelompok dapat meningkatkan kapasitas pembudidaya dalam menjalankan fungsi kelompok dan administrasi kelompoknya, yang berdampak terhadap produktivitas dan pendapatan pembudidaya yang semakin meningkat pula. Hasil yang diperoleh dapat dijabarkan sebagai berikut:

1. Perubahan aspek pengetahuan dan aspek sikap tertinggi berturut-turut diperoleh pada kelompok Mina Mukti dan Cipta Rasa di Kecamatan Darmaraja, Kabupaten Sumedang, Provinsi Jawa Barat yaitu 40\% dan 18\%; disusul pada kelompok Mina Mulya di Kecamatan Landasan Ulin, Kota Banjarbaru, Provinsi Kalimantan Selatan perubahan yang diperoleh untuk aspek pengetahuan dan aspek sikap yaitu $32 \%$ dan $10 \%$; dan terakhir pada kelompok Mina Harapan, Kedung Bulus dan Rukun Makmur di Kecamatan Pangadegan, Kabupaten Purbalingga, Provinsi Jawa Tengah untuk perubahan aspek pengetahuan dan sikap yang diperoleh yaitu $26 \%$ dan $15 \%$.

2. Peningkatan pada aspek pengetahuan di ketiga daerah tersebut dipengaruhi oleh beberapa karakteristik sasaran yaitu umur; pendidikan formal; lama usaha. Sedangkan untuk aspek sikap dipengaruhi oleh partisipasi; dan motivasi.

3. Aspek pengetahuan dan aspek sikap diperoleh persentase tertinggi yaitu 
pada kelompok Mina Mukti dan Cipta Rasa di Kecamatan Darmaraja, Kabupaten Sumedang, Provinsi Jawa Barat karena karakteristik tingkat pendidikan di lokasi tersebut yaitu paling tinggi. Hal ini memengaruhi karakteristik motivasi dan partisipasi juga meningkat sehingga aspek sikap juga mengalami peningkatan.

Saran untuk kegiatan penyuluhan selanjutnya dapat dilakukan di daerahdaerah lain, sehingga dapat mencerminkan peningkatan kapasitas pembudidaya baik hasil usaha perikanan ataupun pendapatan yang meningkat yaitu melalui upaya optimalisasi fungsi wahana pembelajaran kelompok.

\section{PERSANTUNAN}

Kami menyampaikan ucapan terima kasih kepada pihak-pihak yang mendukung kami dalam penulisan jurnal penyuluhan. Khususnya kepada sumber utama, yaitu M. Arya Pratama Putra, S.Tr.Pi.; Nisfi Darwita, S.Tr.Pi.; dan Welas Ayu, S.Tr.Pi.

\section{DAFTAR PUSTAKA}

Ayu, Welas. 2018. "Pembinaan Kelompok Usaha Pembesaran Ikan Lele (Clarias sp) di Kecamatan Pengadengan Kabupaten Perbalingga Provinsi Jawa Tengah [KIPA]." Sekolah Tinggi Perikanan.

Brahmasari, Ida Ayu, dan Agus
Suprayetno. 2008. "Pengaruh motivasi kerja, kepemimpinan dan budaya organisasi terhadap kepuasan kerja karyawan serta dampaknya pada kinerja perusahaan (Studi kasus pada PT. Pei Hai International Wiratama Indonesia)." Jurnal Manajemen dan kewirausahaan 10(2):124-35.

Darwita, Nisfi. 2018. "Peningkatan Kapasitas Pembudidaya Ikan Nila (Oreochoromis nilloticus) Melalui Fungsi Kelompok Di Kecamatan Darmaraja Kabupaten Sumedang Provinsi Jawa Barat [KIPA]." Sekolah Tinggi Perikanan.

Hanan, Abdul. 2015. "Pengaruh Kedinamisan Suatu Kelompok Terhadap Fungsi Kelompok (Studi Kasus Pada Kelompok Perikanan di Kabupaten Bekasi Provinsi Jawa Barat)." Jurnal Penyuluhan Perikanan dan Kelautan 9(1):2942. doi: 10.33378/jppik.v9i1.56.

Koampa, Mario Victorya, Olfie L. S. Benu, Martha M. Sendow, dan Vicky R. B. Moniaga. 2015. "Partisipasi Kelompok Tani dalam Kegiatan Penyuluhan Pertanian di Desa Kanonang Lima Kecamatan Kawangkoan Barat." AGRISOSIOEKONOMI 11(3A):19. doi: 10.35791/agrsosek.11.3A.2015.102 94.

Kogoya, Teraik, Benu Olfie, dan Olly Esry 
Laoh. 2015. "Partisipasi Masyarakat

Terhadap

Pembangunan

Infrastruktur Jalan Desa di

Kabupaten Lanny Jaya-Papua."

EFISIENSI 15(02).

Manyamsari, Ira, dan Mujiburrahmad

Mujiburrahmad. 2014. "Karakteristik

Petani Dan Hubungannya Dengan

Kompetensi Petani Lahan Sempit

(Kasus: Di Desa Sinar Sari

Kecamatan Dramaga Kab. Bogor

Jawa Barat)." Jurnal Agrisep

Unsyiah 15(2):58-74. doi:

10.24815/agrisep.v15i2.2099.

Nurmalia, Nayu, dan Tuti Susilawati.

2016. "Hubungan Kepemimpinan

Ketua Kelompok dengan

Keefektifan Kelompok." Jurnal

Penyuluhan Perikanan dan

Kelautan 10(2):71-87. doi:

10.33378/jppik.v10i2.69.

Pane, Aprida, dan Muhammad Darwis

Dasopang. 2017. "Belajar Dan

Pembelajaran." FITRAH:Jurnal

Kajian IImu-ilmu Keislaman

3(2):333. doi:

10.24952/fitrah.v3i2.945.

Priyandika, Akhbar Nurseta. 2015.

"Analisis Pengaruh Jarak, Lama

Usaha, Modal, Dan Jam Kerja

Terhadap Pendapatan Pedagang

Kaki Limakonveksi (Studi Kasus Di

Kelurahan Purwodinatan Kota

Semarang) [Skripsi]." Universitas

Diponegoro.
Putra, Muhammad Arya Pratama. 2018. "Pendampingan Kelompok Pembesaran Ikan Papuyu Melalui Kegiatan Penyuluhan di Kecamatan Landasan Ulin Kota Banjarmasin Provinsi Kalimantan Selatan [KIPA]." Sekolah Tinggi Perikanan.

Putri, Arya Dwiandana, dan Djinar Setiawina. 2013. "Pengaruh Umur, Pendidikan, Pekerjaan Terhadap Pendapatan Rumah Tangga Miskin di Desa Bebandem." E-Journal EP Unud 2(4):173-80.

Ramadoan, Sri, Pudji Muljono, dan Ismail Pulungan. 2013. "Peran PKSM dalam meningkatkan Fungsi Kelompok Tani dan Partisipasi Masyarakat di kabupaten Bima NTB." Jurnal Penelitian Sosial dan Ekonomi Kehutanan 10(3):199_ 210.

doi:

10.20886/jpsek.2013.10.3.199-210. Sadono, Dwi. 2008. "Pemberdayaan Petani: Paradigma Baru Penyuluhan Pertanian di Indonesia." Jurnal Penyuluhan 4(1). doi:

10.25015/penyuluhan.v4i1.2170.

Sugiyono. 2015. Metode Penelitian Pendidikan (Pendekatan Kuantitatif, Kualitatif, dan $R \& D)$. Bandung (ID): Alfabeta.

Ulfa, Amalia Nadifta, Sri Marwanti, dan Bekti Wahyu Utami. 2015. "Persepsi dan Tingkat Partisipasi Petani 
terhadap Pengembangan Desa

Berbasis Agrowisata (Studi Kasus di

Desa Berjo Kecamatan Ngargoyoso

Kabupaten Karanganyar)." Agrista:

Jurnal IImiah Mahasiswa Agribisnis UNS 3(3):232-38.

Undang-Undang Nomor 13. 2003. tentang Ketenagakerjaan. Indonesia.

Undang-Undang Nomor 20. 2003.

Tentang Sistem Pendidikan

Nasional. Indonesia.

Yani, Diarsi Eka, Ludivica E.S, dan Rinda Noviyanti. 2010. "Presepsi Anggota Terhadap Peran Kelompok Tani
Dalam Meningkatkan Kemampuan Penguasaan Teknologi Budidaya Belimbing." Matematika, Sains, dan Teknologi (JMST) 11(2):133-45.

Yani, Diarsi Eka, Pepi Rospina Pertiwi, dan Argadatta Sigit. 2013. "Partisipasi Anggota Kelompok Tani dalam Menganalisis Data Keadaan pada Usaha Tani Sayuran (Kelompok Tani Sayuran di Desa Margamekar, Kecamatan Pangalengan, Kabupaten Bandung)." Jurnal Matematika Sains dan Teknologi 14(1):62-72. 